DOI: https://doi.org/10.32839/2304-5809/2020-12-88-40

УДК 347.44

Горіславська I.B., Андрощук А.P. Національний університет біоресурсів та природокористування України

\title{
ДО ПИТАННЯ СУБ'СКТНОГО СКЛАДУ ДОГОВОРУ ПРО НАДАННЯ МЕДИЧНИХ ПОСЛУГ
}

\begin{abstract}
Анотація. У статті на основі аналізу діючого національного законодавства, розгляду судової практики та теоретично-правових джерел досліджуються окремі питання суб'єктного складу у договорах про надання медичних послуг. Розкриваються питання набуття та реалізації правосуб’ектності учасників договору про надання медичних послуг. Аналізуються вимоги до надавачів медичних послуг та умови провадження господарської діяльності з медичної практики. Розкривається процедура проведеної експертної оцінки щодо відповідності надавача медичних послуг стандартам акредитації. Досліджується судова практика у справах про застосування відповідальності до надавачів медичних послуг за порушення вимог ліцензування даного виду господарської діяльності. Обгрунтовуються пропозиції щодо усунення недоліків правового регулювання у досліджуваній сфрері.
\end{abstract}

Ключові слова: договір, договір про надання медичних послуг, правосуб'єктність, надавачі медичних послуг, медична практика.

Horislavska Inna, Androshchuk Anastasiia National University of Life and Environmental Sciences of Ukraine

\section{TO THE QUESTION ABOUT THE SUBJECT COMPOSITION OF CONTRACT ON THE PROVISION OF MEDICAL SERVICES}

Summary. The article is based on analysis current national legislation, review of case law and theoretical and legal sources investigate some issues about the subject composition of contract on the provision of medical services. The issues of acquisition and realization of legal personality of the participants of the contract on the provision of medical services are revealed. Requirements to providers of medical services and conditions of conducting economic activity in medical practice are analyzed. The procedure of the expert assessment of the compliance of the medical service provider with the accreditation standards is disclosed. The case law in cases of application of liability to health care providers for violation of licensing requirements for this type of economic activity is studied. Proposals to eliminate the shortcomings of legal regulation in the research area are substantiated. The category of "health" is integrated, the substantive features of which are at the same time: physiological, mental, spiritual well-being. Among the many psychophysiological and socio-psychological factors of health are: biological reliability of the organism; resilience of the individual, indicators of which can be called "healthy" relationships and the availability of opportunities to achieve goals; behavior that involves and involves an active, creative attitude toward one's own health. As a socially oriented society is formed and the dispositive nature of private health care regulation is taken into account, the private sector is gradually being liberalized, although recent developments in the world regarding biological threats and the spread of COVID-19 will suspend this process. Various factors can be cited about the urgency and urgency of issues in the field of health care and directly in relation to the provision of medical services, but a number of objective circumstances speak for themselves about them. The issues of legal regulation of expert assessment regarding the compliance of a health care provider with accreditation standards, the expediency of introducing mandatory accreditation of health care institutions, and a number of other issues remain fully unresolved. In today's challenges, there is a need to study international experience in addressing the issues under study and the use of effective mechanisms that will help ensure the appropriate level of medical services.

Keywords: contract, contract for the provision of medical services, legal personality, medical service providers, medical practice.

Постановка проблеми. Категорія «здоров'я» - інтегрована, змістовними ознаками якої одночасно є: фрізіологічне, психічне, духовне благополуччя людини. 3 поміж багатьох психофрізіологічних та соціально-психологічних фракторів здоров'я можна назвати: біологічну надійність організму; стійкість особистості, показниками якої можна назвати «здорові» відносини та наявність можливостей для реалізації цілей; поведінка, що передбачає та охоплюе активне, творче відношення до власного здоров'я. В умовах, коли формуеться соціально орієнтоване суспільство та враховується диспозитивність приватного регулювання у сорері охорони здоров'я, послідовно відбувається лібералізація приватноправового сектора, хоча останні події у світі, що стосуються біоло- гічних загроз та поширення COVID-19, цей процес призупинять.

Аналіз останніх досліджень та публікацій. Національна наукова думка досліджуваної тематики представлена роботами таких учених як: С.В. Антонов, С.Б. Булеца, I.В. Венедіктова, Д.О. Гомон, А.А. Громов, О.В. Кохановська, О.В. Крилова, Р.А. Майданик, Г.Я. Оверко, О.О. Прасов, В.О. Савченко, О.С. Смотров, С.Г. Стеценко та інші.

Виділення не вирішених раніше частин загальної проблеми. Про гостроту та актуальність питань у сфері охорони здоров'я та безпосередньо щодо надання медичних послуг можна наводити різні фрактори, про них же промовисто «говорить» i низка об'єктивних обставин. Для ефективного правового регулювання статусу 
суб’єктів правовідносин, що виникають при здійсненні медичної діяльності, вже запропоновано: визначити види суб'єктів медичних правовідносин в єдиному нормативному акті - Медичному кодексі; у ЦК України передбачити окремий підрозділ договорів - про надання медичних послуг, про згоду на медичне втручання, про надання медичної допомоги, про медичну таємницю, про відмову пацієнта від лікування тощо; передбачити в ЦК України порядок захисту, компенсації порушених прав медичних працівників та пацієнтів [1]. Проте, повноцінно не вирішеними залишаються питання правового регулювання експертної оцінки щодо відповідності надавача медичних послуг стандартам акредитації, доцільності запровадження обов'язкової акредитації закладів охорони здоров'я та ряд інших питань. В умовах викликів сьогодення $є$ потреба дослідження міжнародного досвіду вирішення досліджуваних питань та застосування ефективних механізмів, що сприятимуть забезпеченню належного рівня медичних послуг.

Метою ціеї статті $е$ дослідження окремих питань правового статусу надавачів медичних послуг на підставі договору.

Виклад основного матеріалу. Відповідно до Закону України «Про державні фрінансові гарантії медичного обслуговування населення» [2] надавачами медичних послуг є заклади охорони здоров'я усіх фрорм власності та фрізичні особи - підприємці, які одержали ліцензію на провадження господарської діяльності 3 медичної практики та уклали договір про медичне обслуговування населення 3 головними розпорядниками бюджетних коштів.

Вимоги до надавача медичних послуг запроваджено на рівні постанови уряду [3] серед основних: наявність ліцензії на провадження господарської діяльності з медичної практики, інших дозвільних документів, передбачених законом; наявність у надавача необхідної для надання послуг 3 медичного обслуговування населення (медичних послуг) за договором матеріальнотехнічної бази, яка відповідає вимогам галузевих стандартів у сорері охорони здоров'я, примірних табелів матеріально-технічного оснащення, затверджених МОЗ. Суб'єкт господарювання, який $є$ закладом охорони здоров'я відповідно до Ліцензійних умов провадження господарської діяльності 3 медичної практики має відповідати 29 вимогам, вичерпний перелік міститься у п. 13 Ліцензійних умов провадження господарської діяльності з медичної практики [4]. Досліджуваний нормативно-правовий акт містить також кадрові та технологічні вимоги (відповідність спеціальним освітнім та кадровим вимогам медичних (фрармацевтичних) працівників для лікарів та провізорів посвідчується: документом про вищу освіту; медичні вироби та вироби медичного призначення повинні застосовуватися ліцензіатом лише: у пристосованих приміщеннях, вимоги до яких визначені в інструкціях із застосування (паспорті) чи технічній документації та інші).

Для отримання ліцензії на здійснення медичної практики необхідно також дотримуватись положень ДБН В 2.2.-9-2009 [5], що серед іншого встановлює вимоги до повітряного середовища та температурного режиму таких приміщень (п. 8.2.), що в свою чергу має відповідати ДСТУ ISO 14644-1:2009. Чисті приміщення та пов'язані 3 ними контрольовані середовища. Частина 1, 2 Класифрікація чистоти повітря та Вимоги до контролювання й моніторингу для підтвердження відповідності (ISO 14644-1:1999, IDT). Судова практика «рясніє» справами про запровадження санкцій до закладів охорони здоров'я, щодо недотримання технологічних вимог та вимог щодо здійснення відповідної діяльності за адресою, що вказана у ліцензії (медичні послуги надаються у непристосованих приміщеннях) [6].

Заклад охорони здоров'я також розміщуе копію акредитаційного сертифріката (за наявності) - позиція Ліцензійних умов здійснення медичної практики, проте доцільно зробити обов'язком для усіх надавачів медичних послуг. Нині порядок акредитації для закладів охорони здоров'я регулюеться постановою Кабінету Міністрів України «Про затвердження Порядку акредитації закладу охорони здоров'я» [7] та є процедурою добровільною. Акредитація закладу охорони здоров'я - це офіційне визнання наявності у закладі охорони здоров'я умов для якісного, своєчасного, певного рівня медичного обслуговування населення, дотримання ним стандартів у сфері охорони здоров'я, відповідності медичних (фрармацевтичних) пращівників єдиним кваліфікацийним вимогам. Вона проводиться після отримання закладом охорони здоров'я ліцензії на провадження господарської діяльності з медичної практики, або ліцензії на провадження господарської діяльності з виробництва лікарських засобів, оптової та роздрібної торгівлі лікарськими засобами, імпорту лікарських засобів, крім активних фрармацевтичних інгредіентів.

Результати проведеної експертної оцінки висвітлюються у експертному висновку про відповідність закладу стандартам акредитації, у якому встановлюються пропозиції щодо акредитації закладу та присвоєння останньому на підставі затверджених Міністерством охорони здоров'я України критеріїв акредитації відповідної акредитаційної категорії (друга, перша, вища) або відмови в акредитащії. У разі прийняття рішення про присвоєння закладу певної акредитаційної категорії відповідна головна акредитаційна або акредитаційна комісія безоплатно видає йому акредитаційний сертифрікат. Строк дії акредитаційного сертифріката не може бути довшим ніж 3 роки та встановлюеться відповідною головною акредитаційною комісією або акредитаційною комісіею з урахуванням рекомендацій, зазначених в експертному висновку.

Ми підтримуемо позицію про те, що тим фрактором, який буде сприяти розвитку медичної сфери, якості медичних послуг та медичного страхування, може стати запровадження обов'язкової умови для виплати страхового відшкодування, як в рамках загальнообов'язкового державного соціального страхування, так і за участю приватних страховиків, наявності у закладу охорони здоров'я акредитаційного сертифріката, що засвідчить офіційне визнання наявності у закладі охорони здоров'я умов для якісного, своєчасного, певного рівня медичного обслуговування населення, дотримання ним стандартів у сорері 
охорони здоров'я, відповідності медичних (dpapмацевтичних) працівників единим кваліфрікаційним вимогам [7].

Так як, наприклад банки пуповинної крові, інших тканин i клітин людини, що обов'язково після отримання ліцензії атестується/акредитується [8]. Одним із таких стандартів є здійснення контролю за бактеріологічним складом повітряного середовища в операційних та інших приміщеннях 3 асептичним режимом роботи, до визначення якого і має застосовується ДСТУ ISO 14644-1:2009. Необхідно привести до одного знаменника санітарні нормам і правила для всіх закладів охорони здоров'я, оскільки одні з них застаріли, інші, наприклад, Державні санітарні норми і правила "Санітарно-протиепідемічні вимоги до закладів охорони здоров'я, що надають первинну медичну (медико-санітарну) допомогу» та Державні санітарні норми та правила «Гігієнічні вимоги до розміщення, облаштування, обладнання та експлуатації перинатальних центрів» стосуються окремих категорій закладів охорони здоров'я.

До кола учасників, що можуть стати стороною договору про надання медичних послуг не відносяться малолітні особи, особи, що позбавлені дієздатності або обмежені у дієздатності у за- конний спосіб. 3 іншого боку, іноземці, особи без громадянства відповідно до Порядку вибору лікаря, який надає первинну медичну допомогу, та форми декларації про вибір лікаря, який надає первинну медичну допомогу [9] мають право на укладення договору про надання медичної послуги.

Висновки і пропозиції. Суб’єкти права на медичну допомогу та суб'єкти договірних правовідносин у медичній сфрері - поняття не тотожні. Аналіз нормативно-правових актів у сорері охорони здоров'я дає підстави виділити наступних учасників договірних відносин у цій copepi: a) суб'єкти, що надають медичні послуги; б) суб'єкти, що «споживають» медичні послуги; в) суб'єкти, які реалізують державну політику у сорері охорони здоров'я, зокрема, надання медичних послуг. Доцільно запровадити, принаймні на перспективу, обов'язкову акредитацію для усіх надавачів медичних послуг, це стане тим фрактором, який буде сприяти розвитку медичної сфери, якості медичних послуг та медичного страхування, може стати запровадження обов'язкової умови для виплати страхового відшкодування, як в рамках загальнообов'язкового державного соціального страхування, так і за участю приватних страховиків.

\section{Список літератури:}

1. Булеца С.Б. Цивільні правовідносини, що виникають у сфрері здійснення медичної діяльності: теоретичні та практичні проблеми : дис. ... д-ра юрид. наук : 12.00. 03 / Національний університет «Одеська юридична академія». Одеса, 2016. 437 с.

2. Про державні фінансові гарантії медичного обслуговування населення : Закон України від 19.10.2017 № 2168-VIII. URL: https://zakon.rada.gov.ua/laws/show/2168-19\#Text (Редакція від 03.07.2020).

3. Про затвердження вимог до надавача послуг з медичного обслуговування населення, з яким головними розпорядниками бюджетних коштів укладаються договори про медичне обслуговування населення : Постанова Кабінету Міністрів України від 28 березня 2018 р. № 391. URL: https://zakon.rada.gov.ua/laws/show/391-2018\%D0\%BF\#Text (Редакція від 19.09.2020).

4. Про затвердження Ліцензійних умов провадження господарської діяльності з медичної практики : Постанова Кабінету Міністрів України від 2 березня 2016 р. № 285. URL: https://zakon.rada.gov.ua/laws/show/2852016-\%D0\%BF\#Text (Редакція від 20.03.2019).

5. ДБН В 2.2.-9-2009 Державні будівельні норми України «Будинки і споруди. Громадські будинки і споруди. Основні положення» : наказ Міністерства регіонального розвитку та будівництва України № 705 від 17.12 .2009 та від 15.07.2010 № 264, чинні з 2010-10-01. URL: https://www.minregion.gov.ua/wp-content/uploads/2017/12/ 58.1.-DBN-V.2.2-9-2009.-Budinki-i-sporudi.-Gromadski-bu.pdf (дата звернення: 11.12.2020).

6. Рішення Івано-Франківського окружного адміністративного суду від 03.08.2020 p. № 300/959/20. URL: https://reyestr.court.gov.ua/Review/90724049 (дата звернення: 11.12.2020).

7. Порядок акредитації закладу охорони здоров'я : Постанова Кабінету Міністрів України від 15 липня 1997 року № 765. URL: https://zakon.rada.gov.ua/laws/show/765-97-\%D0\%BF\#Tеxt (Редакція від 20.03.2019).

8. Про затвердження Ліцензійних умов провадження господарської діяльності банків пуповинної крові, інших тканин і клітин людини згідно з переліком, затвердженим Міністерством охорони здоров'я : Постанова Кабінету Міністрів України від 2 березня 2016 р. № 286. URL: https://zakon.rada.gov.ua/laws/show/286-2016\%D0\%BF\#Text (Прийняття від 02.03.2016).

9. Про затвердження Порядку вибору лікаря, який надає первинну медичну допомогу, та фоорми декларації про вибір лікаря, який надає первинну медичну допомогу : наказ Міністерства охорони здоров'я України 19.03.2018 № 503. URL: https://zakon.rada.gov.ua/laws/show/z0347-18\#Text (Редакція від 03.07.2018).

\section{References:}

1. Buletsa S.B. (2016) Tsyvilni pravovidnosyny, shcho vynykaiut u sferi zdiisnennia medychnoi diialnosti: teoretychni ta praktychni problemy [Civil legal relations arising in the field of medical activities: theoretical and practical problems]. Odessa, $437 \mathrm{p}$.

2. The Law of Ukraine (October 19, 2017). Pro derzhavni finansovi harantii medychnoho obsluhovuvannia naselennia № 2168-VIII. [About the state financial guarantees of medical service of the population]. Kyiv: Verkhovna Rada of Ukraine. (Editorial series "The Law of Ukraine"). Available at: https://zakon.rada.gov.ua/laws/show/2168-19\#Text (accessed 03.07.2020).

3. Resolution of the Cabinet of Ministers of Ukraine (Mach 28,2018). Pro zatverdzhennia vymoh do nadavacha posluh z medychnoho obsluhovuvannia naselennia, z yakym holovnymy rozporiadnykamy biudzhetnykh koshtiv ukladaiutsia dohovory pro medychne obsluhovuvannia naselennia № 391 [About the statement of requirements to the provider of services in medical service of the population with whom the main managers of budgetary funds conclude agreements on medical service of the population]. Kyiv: Verkhovna Rada of Ukraine. (Editorial series "The Law of Ukraine"). Available at: https://zakon.rada.gov.ua/laws/show/391-2018-\%D0\%BF\#Text (accessed 19.09.2020). 
4. Resolution of the Cabinet of Ministers of Ukraine (Mach 2, 2016). Pro zatverdzhennia Litsenziinykh umov provadzhennia hospodarskoi diialnosti z medychnoi praktyky № 285 [About the statement of License conditions of carrying out economic activity on medical practice]. Kyiv: Verkhovna Rada of Ukraine. (Editorial series "The Law of Ukraine”). Available at: https://zakon.rada.gov.ua/laws/show/285-2016-\%D0\%BF\#Text (accessed 20.03.2019).

5. Order of the Ministry of Regional Development and Construction of Ukraine (December 17, 2009). DBN V 2.2.-9-2009 Derzhavni budivelni normy Ukrainy «Budynky i sporudy. Hromadski budynky i sporudy. Osnovni polozhennia» № 705 [DBN B 2.2.-9-2009 State building codes of Ukraine "Buildings and structures. Public buildings and structures. Substantive provisions"]. Available at: https://www.minregion.gov.ua/wp-content/ uploads/2017/12/58.1.-DBN-V.2.2-9-2009.-Budinki-i-sporudi.-Gromadski-bu.pdf (accessed 11.12.2020).

6. Rishennia № 300/959/20 (2020) [Court decision № 300/959/20]. Ivano-Frankivskoho okruzhnoho administratyvnoho sudu. Available at: https://reyestr.court.gov.ua/Review/90724049 (accessed 11.12.2020).

7. Resolution of the Cabinet of Ministers of Ukraine (July 15, 1997). Poriadok akredytatsii zakladu okhorony zdorovia № 765 [Procedure for accreditation of a health care institution]. Kyiv: Verkhovna Rada of Ukraine. (Editorial series "The Law of Ukraine"). Available at: https://zakon.rada.gov.ua/laws/show/765-97-\%D0\%BF\#Text (accessed 20.03.2019).

8. Resolution of the Cabinet of Ministers of Ukraine (Mach 2, 2016). Pro zatverdzhennia Litsenziinykh umov provadzhennia hospodarskoi diialnosti bankiv pupovynnoi krovi, inshykh tkanyn i klityn liudyny zghidno z perelikom, zatverdzhenym Ministerstvom okhorony zdorovia № 286 [About the statement of Licensing conditions of carrying out economic activity of banks of umbilical cord blood, other fabrics and human cells according to the list approved by the Ministry of Health]. Kyiv: Verkhovna Rada of Ukraine. (Editorial series "The Law of Ukraine"). Available at: https://zakon.rada.gov.ua/laws/show/286-2016-\%D0\%BF\#Text (accessed 02.03.2016).

9. Order of the Ministry of Health of Ukraine (Mach 19, 2018). Pro zatverdzhennia Poriadku vyboru likaria, yakyi nadaie pervynnu medychnu dopomohu, ta formy deklaratsii pro vybir likaria, yakyi nadaie pervynnu medychnu dopomohu № 503. [About the statement of the Procedure for a choice of the doctor providing primary medical care, and the form of the declaration on a choice of the doctor providing primary medical care]. Kyiv: Verkhovna Rada of Ukraine. (Editorial series "The Law of Ukraine"). Available at: URL: https://zakon.rada.gov.ua/laws/show/z034718\#Text (accessed 03.07.2018). 